\title{
Letter to the Editor Regarding "Gabapentin has Longer-Term Efficacy for the Treatment of Chronic Pelvic Pain in Women: A Systematic Review and Pilot Meta-analysis"
}

\author{
Katy Vincent (D) - Andrew W. Horne $\cdot$ Jane P. Daniels
}

Received: October 22, 2021 / Accepted: December 21, 2021 / Published online: January 19, 2022

(C) The Author(s) 2022

Keywords: Gabapentin; Chronic pelvic pain; Systematic review; Meta-analysis

\section{Key Summary Points}

Gabapentin is a drug with evidence of efficacy in neuropathic pain that has been increasingly used in other chronic pain conditions without robust supporting data.

An adequately powered study showed no benefit of gabapentin over placebo for this indication at 3 months with high rates of side effects.

This is a response article where we highlight our concerns about the suggestion that gabapentin may have longer-term efficacy for the treatment of chronic pelvic pain in women.

K. Vincent $(\bowtie)$

Nuffield Department of Women's and Reproductive Health, John Radcliffe Hospital, University of Oxford, Headley Way, Oxford OX3 9DU, UK e-mail: katy.vincent@wrh.ox.ac.uk

\section{A. W. Horne}

MRC Centre for Reproductive Health, Queen's Medical Research Institute, University of Edinburgh, Edinburgh EH16 4TJ, UK

\section{J. P. Daniels}

Nottingham Clinical Trials Unit, University of

Nottingham, Nottingham NG7 2RD, UK
Dear Editor,

We were concerned to read the article entitled "Gabapentin has Longer-Term Efficacy for the Treatment of Chronic Pelvic Pain in Women: A Systematic Review and Pilot Meta-analysis", published recently by Fan and colleagues [1], which concluded that gabapentin could be a potential treatment option for chronic pelvic pain in women. We believe that the methodology used in this systematic review is inappropriate, and thus draws erroneous conclusions with the potential to expose women with chronic pelvic pain to unnecessary risk.

Gabapentin is a drug with evidence of efficacy in neuropathic pain [2] that has increasingly been used in other chronic pain conditions despite a lack of robust data to support its use [3-6]. Not only are there a range of unpleasant side effects associated with gabapentin, but there is also a very real risk of addiction and abuse potential as seen in both European and US populations [7, 8].

We recently published the findings of a large multicentre, randomised, placebo-controlled trial exploring the efficacy and safety of gabapentin in women with chronic pelvic pain and no obvious pelvic pathology [9]. We compared gabapentin to placebo in 306 women (153 per group) and found no significant difference in any of our primary or secondary outcomes. However, we did observe a higher proportion of 
serious adverse events and other known side effects in those using gabapentin. The trial was designed after completion of a pilot study [10] comparing gabapentin to placebo in 47 women ( $n=22$ vs. $n=25$, respectively).

In their systematic review and meta-analysis, Fan and colleagues combine data from our two trials with two further studies: a pilot study comparing gabapentin to amitriptyline $(n=20$ vs. $n=20)$ and to a combination of gabapentin and amitriptyline $(n=16)$ [11] (although only the first comparison is included in this review); and a single-centre trial comparing gabapentin to placebo in 60 women (30 per group) [12]. Only our trial is considered to have a low risk of bias [9], with the two remaining studies generously assessed as unclear [10,12] and of having a high risk of bias [11]. The meta-analysis reports two primary outcomes (change in pain scores at 3 and 6 months) and a number of secondary outcomes. The only outcomes for which a significant difference between the gabapentin and control groups was identified were change in pain scores at 3 and 6 months and the adverse effects of dizziness and somnolence. Importantly, our full randomised controlled trial (RCT) assessed outcomes at 13-16 weeks of treatment and thus the metaanalysis of data reported at 6 months does not include data from this study, the largest of the datasets. Nonetheless, the authors conclude that "whilst the change in pain scores failed to meet the threshold for a MCID (minimally clinically important difference) during the 3-month period, the changes were higher than MCID during the 6-month period". We would additionally argue that the use of change in pain scores is inappropriate as it does not take account of baseline pain severity.

Given that our large adequately powered trial with low risk of bias [9] found no benefit of gabapentin over placebo at 3 months and identified a high rate of side effects (and that gabapentin has such recognised abuse and addictive potential that it has been reclassified as a controlled drug in the UK), we do not feel it is appropriate to suggest that studies with longer dosing periods be carried out on the basis of meta-analysis of data from three studies including only 147 women in total.

\section{ACKNOWLEDGEMENTS}

Funding. No funding or sponsorship was received for this study/letter or publication of this article.

Authorship. All named authors meet the International Committee of Medical Journal Editors (ICMJE) criteria for authorship for this article, take responsibility for the integrity of the work as a whole, and have given their approval for this version to be published.

Authors' Contributions. All authors discussed the preparation and content of this letter. Katy Vincent drafted the letter. Andrew W. Horne and Jane P. Daniels revised the manuscript. All authors approved the final version.

Disclosures. Katy Vincent has received research funding from Bayer Healthcare and Honoraria and travel expenses for consultancy and lectures from Bayer Healthcare, AbbVie, Grunenthal $\mathrm{GmBH}$, and Eli Lilly. AWH reports grant funding from the MRC, NIHR, CSO, Wellbeing of Women, Roche Diagnostics, Astra Zeneca, Ferring, Charles Wolfson Charitable Trust, Standard Life, Consultancy fees from Roche Diagnostics, AbbVie, Nordic Pharma and Ferring. In addition, Andrew W. Horne has a patent pending for a serum biomarker for endometriosis. Jane P. Daniels reports no disclosures.

Compliance with Ethics Guidelines. This article is based on previously conducted studies and does not contain any new studies with human participants or animals performed by any of the authors.

Data Availability. All data are described in previously published manuscripts. Data sharing is not applicable to this article as no datasets were generated or analysed during the current study.

Open Access. This article is licensed under a Creative Commons Attribution-NonCommercial 4.0 International License, which 
permits any non-commercial use, sharing, adaptation, distribution and reproduction in any medium or format, as long as you give appropriate credit to the original author(s) and the source, provide a link to the Creative Commons licence, and indicate if changes were made. The images or other third party material in this article are included in the article's Creative Commons licence, unless indicated otherwise in a credit line to the material. If material is not included in the article's Creative Commons licence and your intended use is not permitted by statutory regulation or exceeds the permitted use, you will need to obtain permission directly from the copyright holder. To view a copy of this licence, visit http:// creativecommons.org/licenses/by-nc/4.0/.

\section{REFERENCES}

1. Fan XM, Ren YF, Fu X, et al. Gabapentin has longerterm efficacy for the treatment of chronic pelvic pain in women: a systematic review and pilot metaanalysis. Pain Ther. 2021. https://doi.org/10.1007/ s40122-021-00330-4.

2. Finnerup NB, Attal N, Haroutounian S, et al. Pharmacotherapy for neuropathic pain in adults: a systematic review and meta-analysis. Lancet Neurol. 2015;14(2):162-73.

3. Cooper TE, Derry S, Wiffen PJ, Moore RA. Gabapentin for fibromyalgia pain in adults. Cochrane Database Syst Rev. 2017;1:CD012188.

4. Alviar MJ, Hale T, Dungca M. Pharmacologic interventions for treating phantom limb pain. Cochrane Database Syst Rev. 2016;10:CD006380.
5. Enke O, New HA, New $\mathrm{CH}$, et al. Anticonvulsants in the treatment of low back pain and lumbar radicular pain: a systematic review and meta-analysis. CMAJ. 2018;190(26):E786-93.

6. Goodman CW, Brett AS. A clinical overview of offlabel use of gabapentinoid drugs. JAMA Intern Med. 2019;179(5):695-701.

7. Chiappini S, Schifano F. A decade of gabapentinoid misuse: an analysis of the European Medicines Agency's "Suspected Adverse Drug Reactions" database. CNS Drugs. 2016;30(7):647-54.

8. Evoy KE, Covvey JR, Peckham AM, Ochs L, Hultgren KE. Reports of gabapentin and pregabalin abuse, misuse, dependence, or overdose: an analysis of the Food And Drug Administration Adverse Events Reporting System (FAERS). Res Social Adm Pharm. 2019;15(8):953-8.

9. Horne AW, Vincent K, Hewitt CA, et al. Gabapentin for chronic pelvic pain in women (GaPP2): a multicentre, randomised, double-blind, placebo-controlled trial. Lancet. 2020;396(10255):909-17.

10. Lewis SC, Bhattacharya S, Wu O, et al. Gabapentin for the management of chronic pelvic pain in women (GaPP1): a pilot randomised controlled trial. PLoS ONE. 2016;11(4): e0153037.

11. Sator-Katzenschlager SM, Scharbert G, Kress HG, et al. Chronic pelvic pain treated with gabapentin and amitriptyline: a randomized controlled pilot study. Wien Klin Wochenschr. 2005;117(21-22): 761-8.

12. AbdelHafeez MA, Reda A, Elnaggar A, El-Zeneiny H, Mokhles JM. Gabapentin for the management of chronic pelvic pain in women. Arch Gynecol Obstet. 2019;300(5):1271-7. 